\title{
KHARKIV MUSICIANS THE MARECHEKS: ANCESTRY - FINDINGS - NEW RIDDLES
}

\section{Vasyl Shchepakin}

\section{INTRODUCTION}

In the history of the Kharkiv musical culture despite the collective and research activities there is a number of well known and dedicated scientists and music regional ethnographers of different times: T. Bakhmet, V. Berlin, spouses V. Bogdanov and L. Bogdanova, O. Chepalov, O. Kononova, V. Kravets, M. Linnik, Yu. Loshkov, L. Lysenko, I. Miklashevsky, V. Osadcha, O. Pinchuk, I. Polska, I. Polsky, A. Rumyantseva, Yu. Shcherbinin, G. Tyumeneva, Yu. Vahranev, Z. Yuferova, N. Zymohlyad, and others, so far, many "white spots" still exist. A number of names of the musicians of the past, who made an invaluable contribution to the formation of the professional music education and performance, were either half-forgotten or unknown not only to the wide musical and cultural community of the Slobojanshchina capital, but also to many specialists in this field.

In the recent decades a whole layer of some deep scientific researches appear, that are devoted to the presentation of the creative portraits (and sometimes of the reconstruction of life and the creative paths) of many famous musicians of the past, whose activities were closely connected with Kharkiv. However, a lot of more names of bright and outstanding personalities of the past - forgotten or half-forgotten, are waiting for the return to the tablets of the Slobojanshchina history.

Despite the existence of a number of scientific publications on the problem of the creative application of their professional abilities on the territory of Sloboda by the foreign, in particular by the Czech musicians ${ }^{1,2,3}$, up to these days this perhaps the most significant component of the history of the city musical culture requires some more careful study.

During the last quarter of the XIX - the first half of the XX century, the Czech surname Marechek was well known to the Kharkiv musical

${ }^{1}$ Shchepakin V. M. (ed). (2005). Czech musicians in Ukraine: Bibliographic Dictionary. Ministry of Culture and Tourism of Ukraine, Kharkiv State Academy of Culture. Kharkiv: KhDAC.

${ }^{2}$ Shchepakin V. M. (2017). Musical culture of the East and South of Ukraine in the second half of the $19^{\text {th }}$ - beginning of the $20^{\text {th }}$ centuries: European dimensions. Kharkiv: FOP Panov A. M.

${ }^{3}$ Shchepakin V. M. (2001). Activity of Czech military capmillers in Ukraine in the second half of XIX - early XX centuries. Culture of Ukraine. Art Studies, vol. 8. Pp. 198-205. 
community, because several generations of this family have been working in the city, covering various musical spheres and vectors of activity. However, unfortunately, at the beginning of the XXI century this musical family appeared to be almost forgotten.

So, the purpose of this work is to try to at least partially fill one of the gaps in the study of the history of development of the Kharkiv musical culture.

This goal led to the following research tasks:

- to outline the musical activity areas of three generations of the Marechek family in Kharkiv;

- on the basis of the analyzed documents from the Kharkiv periodicals, reference publications, individual scientific and internet publications, as well as from the found archival materials, to at least schematically reconstruct the life paths and to recreate the creative biographies of the Marechek family representatives, connected with the musical activity;

- to determine the role of the Marechek musical family in the musical and cultural life of the city in the last quarter of the XIX - the first half of the XX century.

In order to perform the set tasks, the following was involved in the work process:

- the historical approach that allowed us to analyze the lives and the activities of this research work characters in the context of the historical, cultural and political processes, which took place in the corresponding times;

- the method of the biographical reconstruction, which revealed the most significant facts in the life and creative biographies of the Marechek family representatives;

- the musical ethnographic method that contributed to the study of the problem in a close connection with the musical and cultural realities of Kharkiv in the late XIX - the first half of the XX century.

The long-term searches in the Kharkiv archives, the study of the periodicals and reference publications and the mutual assistance in searching for materials on the designated topic of the author of this research work and T. E. Solyanik - the great-granddaughter of the spouses F. V. and N. V. Marechek, who lives with her family in Odessa and without being a musician by profession, has a musical education and is deeply knowledgeable in the musical culture history, including the topics related to the musical activities of her ancestors, as well as the kind provision of a number of archival sources by the curator of the musical and cultural memory of Kharkiv, the founder of the public Museum "The amulets of the musical Kharkiv" Yu. L. Shcherbinin, made this publication possible. 


\section{Kharkiv military kapellmeister Frantisek Marechek}

According to the archival materials, provided in the Old German language from the Czech Republic to T. Solyanik, the Czech musician Frantisek Wojciechowicz Marechek (21 October 1834, Slivno, near Mala Boleslava 20 May 1899, Kharkiv) was the founder of this musical dynasty, he came from a family of a rural tailor Wojciech Marechek, who according to T. Solyanik, in 1871 moved from the Czech Republic to the Russian Empire, having accepted the duties of a free-lance kapellmeister of the orchestra of the $121^{\text {st }}$ Penza infantry regiment ${ }^{4}$. In the Russian-language annual Kharkiv calendars and on the pages of the local newspapers, in addition to the mentioned above name and patronymic of this musician, there are at least two different versions of it in the Russian manner: Franz Wojciechowicz and Viktor Vyacheslavovich (the last in the second half of the $1890^{\mathrm{s}}$ ).

According to the information provided by $\mathrm{T}$. Solyanik from the annual reference publications "The Kharkiv calendar", in 1871 the $121^{\text {st }}$ Penza infantry regiment was stationed in Kursk, the next year it was transferred to Stary Oskol, where it was located till $1873^{5}$. Since 1874 the regiment was relocated to Kharkiv, where it was located in the barracks on Moskalevka then it was the outskirts and now it is one of the oldest historical districts of the city.

In his choice of the country and the place of work, the Czech F. V. Marechek was far from isolated, because in the XIX century in the Russian Empire, in particular in the regions of Ukraine that were part of it, there was a significant lack of their own professional musicians, while in the Czech Republic, which in the XVIII century was called by the contemporaries the "Conservatory of Europe", weighing in on the mass music awareness in any stratum of society - from the Czech aristocracy to the peasants - their significant "overproduction" could be felt, because in those days, when the professional music training at the state level in the Russian Empire had nothing to dream of, in the Czech Republic an extensive system of training professional musicians already operated - from Church schools and private educational institutions to the Prague Conservatory opened in 1811 - the third in Europe after the Paris (1784) and the Milan (1807) ones, the Prague organ school and so on. That is why thousands of Czech highly professional musicians in search of a job and a decent reward for their skills and the ability to put their talent into practice, have held various positions in the musical sphere not only in the Russian Empire, but also in many countries of Europe and the world.

\footnotetext{
${ }^{4}$ Solyanik T. E. (2015). Frantisek Wojciechowicz Marecek (unpublished). P. 1.

${ }^{5}$ Solyanik T. E. (2015). Frantisek Wojciechowicz Marecek (unpublished). P. 2.
} 
The first found mention of F. V. Marechek and the military orchestra directed by him, called namely "The military trumpeters chorus", on the pages of the Kharkiv newspapers reaches $1876^{6}$, when in the infantry regiments of the Russian Empire 35-man orchestras "with copper instruments" were set. Soon, in 1883 , by the order of the war Ministry it was allowed to introduce woodwind instruments into the military orchestras, along with brass ones ${ }^{7}$.

From the historical documents it is known that the $121^{\text {st }}$ Penza infantry regiment took an active part in the Russian-Turkish war of 1877-1878 on the territory of the present-day Bulgaria, in particular in the liberation of Nikopol and in the bloody battles near Pleven, when the regiment lost 27 officers and 955 soldiers of lower ranks only during one battle on July the $18^{\text {th }}$, and also after the occupation of Pleven by the Russian army, in the battle near the village of Girske Bugarove. For the heroism demonstrated in this battle, which took place on December the $20^{\text {th }}, 1877$, the $2^{\text {nd }}$ and $3^{\text {rd }}$ battalions of the Penza regiment received the St. George's flags as a special award and the $1^{\text {st }}$ battalion received the St. George's trumpets ${ }^{8}$.

Of course F. V. Marechek being in Bulgaria with his regiment could not help being a participant or at least a direct witness to these battles, because the military orchestra playing was an indispensable attribute of the battles of those times. The words of the outstanding commander O. V. Suvorov became a popular expression: "Music doubles, triples the army. With the cross in the priest's hand, the flags flying and with the loud music I took Ismail"" . The great role of the military orchestras during the battle of Pleven was noted by the historian of military music V. Tutunov ${ }^{10}$. After the end of hostilities the regiment still participated in the taming of the Turks, who rebelled in the Rhodope mountains, then it remained in Bulgaria as part of the occupation forces. Finally, more than two years later, on June the $29^{\text {th }} 1879$, on the day of its regimental holiday, the Penza regiment returned to Kharkiv ${ }^{11}$.

\footnotetext{
${ }^{6}$ Kharkov provincial statements. (1876). The part is unofficial. [On the performance of the $121^{\text {th }}$ Penza Infantry Regiment's Orchestra led by F. Marechek]. 5 September.

${ }^{7}$ Tutunov V. I. (1961). 250 years of military service in Russia (brief historical sketch). Proceedings of the military conducting faculty at the Moscow Tchaikovsky State Conservatory. Moscow: Moscow Tchaikovsky State Conservatory. Vol. 5. pp. 126-140.

${ }^{8}$ Schenk V. K. (1909). Grenadier and Infantry regiments. $121^{\text {st }}$ Infantry Penza General Field Marshal Count Milyutin Regiment. Reference book of the Imperial Headquarters. Military encyclopedia of Sytin, vol. 18. Retrieved from : http://www.imha.ru/1144528148-pexotnyj-121go-penzenskij-general-feldmarshala.html\#.XjsVLDIzbbh (accessed 29 January 2020).

${ }^{9}$ Balyazin V. N. (2007). Unofficial History of Russia. Moscow: OLMA Media Group, 2007. P. 49.

${ }^{10}$ Tutunov V. I. (1961). 250 years of military service in Russia (brief historical sketch). Proceedings of the military conducting faculty at the Moscow Tchaikovsky State Conservatory. Moscow: Moscow Tchaikovsky State Conservatory. Vol. 5. P. 131.

${ }^{11}$ Levchenko A. (2007). How Kharkiv citizens fought with the Turks. Evening Kharkov. 12 March.
} 
Namely under the impression of the Russo-Turkish war during the stay of the $121^{\text {st }}$ Penza infantry regiment in Bulgaria, F. V. Marecheka, whose orchestra was attached to the Bulgarian people's irregulars, wrote his work "Shumi, Maritza" - one of the very first version of the Bulgarian anthem, in which the kapellmeister, having added some folklore motifs to the already existing variant, tried to combine more tightly the music with the text of this work, because between these two components, according to Bulgarian researchers, there was a significant artistic contradiction ${ }^{12}$.

Besides the above-mentioned processing of the Bulgarian national anthem, F. Marechek is also the author of polka for the piano "The Joke", printed in 1890 in Kharkiv typography of Adolf Darré on the Moscow Street, 19, the next house where the Marecheks lived ${ }^{13}$. F. V. Marechek also wrote the "Abyssinian Military March", dedicated to the Ethiopian Emperor Menelik II, published in a piano version in December 1897 by the same music printing house $^{14}$. This work was first performed by the orchestra of the $121^{\text {st }}$ Penza infantry regiment according to the manuscript during the crowded opening of the Abyssinian exhibition in Kharkiv, which took place on November the $30^{\text {th }}$ of the same year in the house of Yunurovsky on Kontorskaya Street. As it was noted by the local press, this exhibition consisted of three sections: the ethnic section, the one of the items of equipment and the section of the results of the Russian sanitary detachment in Abyssinia, with a total of about 400 exhibits, and aroused a great interest of the visitors, among whom there were many foreigners $^{15}$. So, the performance of the military orchestra directed by F. V. Marechek during this event became a bright artistic and cultural event.

It should be noted that the concert life of Kharkiv during the last third of the XIX century took place mainly with the participation of several visiting civilian small orchestras, among which the orchestra "PhilharmonicGermany", headed by G. Gene, stood out for its harmony and fullness of sound, and among the local musical bands that filled the Kharkiv cultural life, almost the brightest orchestra was the one of the $121^{\text {st }}$ Penza infantry regiment under the direction of F. V. Marechek, because the common practice of military orchestras in the Russian Empire, as by the way in other European countries, first of all in the Austro-Hungarian Empire, which included the Czech lands - Bohemia and Moravia, Germany, France and others, in those days, except for the use of the orchestra for its intended purpose, i.e. serving

${ }^{12}$ Vojnikov I. (2017). History of Bulgarian national symbols. V. Turnovo: Abagar.

${ }^{13}$ Sozonova V. M., Lubenska N. V. (ed.) (2012). Ukrainian music editions in the fund of Kharkiv Korolenko State Scientific Library. (1864-1923): a catalog. Kharkiv: State Institution "Kharkiv Korolenko State Scientific Library". P. 147.

${ }^{14}$ South edge (1897). Abyssinian Military March. 8 December.

${ }^{15}$ South edge (1897). Abyssinian exhibition. 1 December. 
the actual military needs of a particular military unit, such musical groups were indispensable participants and signs of the cultural life of the cities, where the military units were stationed. Thanks to this talented military kapellmeister the orchestra of the $121^{\text {st }}$ Penza infantry regiment, in addition to the staff schedule of the performers, playing wind and percussion instruments and a fairly narrow mandatory military repertoire, necessary to accompany the daily drill on the parade ground, parades, guard breeding and so on, significantly enriched its repertoire with secular popular and dance music (in particular, to serve the needs of the summer recreation Park in Kharkiv) and with a separate group of string instruments, which joined the brass during the playing at balls, masquerades and special (festive and solemn) social events, organized by the local community (turning into a so-called "ballroom orchestra"). In comparison with the usual military music bands in the provincial cities of the Russian Empire such an orchestra was a rare phenomenon at that time. As a rule, performers, playing bowed string in such bands include, along with a small number of professional musicians, who could be concertmasters of some individual groups (violins, violas, cellos and double basses), amateur musicians from the composition of the officers, civilian employees of the regiment and (or) members of their families.

Here is a typical announcement of the performance of this group (1889): "On Saturday, April the $29^{\text {th }}$ the Kharkiv tram Directorate proposes to arrange some "festivities" in the University garden. The military orchestra of the Penza regiment under the direction of F. V. Marechek will perform several plays for this special program, including "The Great Russian dawn" with the participation of 20 drums" $" 16$.

F. V. Marechek's authority as a conductor among the musicians of Kharkiv was so significant, that it was he who was assigned to lead the combined military orchestra, which included musicians from the $121^{\text {st }}$ Penza, the $122^{\text {nd }}$ Tambov and the $124^{\text {th }}$ Voronezh infantry regiments during city holidays and the major charity concerts, the total number of musicians was up to $150^{17}$. The fact of performing in the same concert of the consolidated string orchestra, which consisted of professional musicians of the Opera and drama theaters, as well as of students of the music school under the guidance of a respected and authoritative musician and conductor in Kharkiv, the director of the music school of the Kharkiv branch of the Imperial Russian musical society of I. I. Slatin, indirectly testifies the corresponding level of F. V. Marechek and of the combined group of military musicians under his direction.

\footnotetext{
${ }^{16}$ Kharkov provincial statements (1889). The Chronicle. 28 April.

${ }^{17}$ South edge (1896). The ads. 1 February.
} 
A confirmation of the orchestra high level is also the fact that in the early $1890^{\mathrm{s}}$ this particular group was constantly involved in the production of the city opera by G. Meyerber "Huguenots", in which in addition to the opera orchestra in the orchestra pit, a brass band on the stage was also used ${ }^{18}$.

For 25 or 26 years of leading the orchestra of the $121^{\text {st }}$ Penza infantry regiment, a record period for that times (!), if we compare the time of work of other kapellmeisters with military orchestras in the Russian Empire, F. V. Marechek turned it from a traditional craft-level collective for the vast majority of Russian army enlisted men at the beginning of his career to a wellorganized brass band with a high professional training, which was fairly considered by the contemporaries to be the best among several similar orchestras of other military units, whose places of permanent residence were Kharkiv and Chuguev, which was geographically close to it.

To the activity as a kapellmeister, the composing and the organizational spheres of activity of this Czech kapellmeister, it is necessary to add the music and pedagogical activity, because despite the fact that F. V. Marechek did not work in any of the special musical or general educational institutions of Kharkiv, he undoubtedly taught the military band members at least the basics of the musical literacy, playing wind instruments and nurtured their general musical taste necessary for the correct understanding, interpretation and performance of various music, that was part of the repertoire of his orchestra. A confirmation of this statement is the fact that since 1889 in the military units of the Kharkiv garrison they began to organize some small (5-6 boys each) student teams attached to the regimental orchestras, in which children from low-income families capable of music were accepted with full maintenance for a period of 5 years. During this period the military kapellmeisters taught them to play in the orchestra. After the graduation the musicians were required to serve in the orchestra for a fee for two years, after which if desired they were liberated from further military service. In 1897, i.e. at the end of the kapellmeister service of F. (V.) V. Marechek, the number of such pupils in some regiments reached 20 people $^{19}$.

F. (V.) V. Marechek served as kapellmeister of the orchestra of the $121^{\text {st }}$ Penza infantry regiment until 1897 inclusively. In 1898 he was no longer listed on the regiment's staff. However, at the end of February 1899, less than three months before his death, he led the string-and-brass ("ballroom") orchestra at the Military Assembly probably for the last time ${ }^{20}$. According to the memories of F. V. Marechek's eldest son, Vladimir, kindly provided by

\footnotetext{
${ }^{18}$ Rudenko V. I. (1984). Vyacheslav Ivanovich Souk: Popular monograph. Moscow: Music. P. 45.

${ }^{19}$ South edge. (1897). Music students. 15 February.

${ }^{20}$ Kharkov provincial statements (1899). Private Ads. 25 February.
} 
T. Solyanik, his father, an Austrian citizen, received the Russian citizenship only at the end of his life. Until 1896 inclusively he was listed in the annual "Kharkiv calendars" as Franchishek or Frantz, but in 1897 already as Viktor. Therefore, as T. Solyanik fairly notes, since the editions of the "Kharkiv calendar" were made up at the end of the current year for the next one, it is likely that he took both the Russian name and the citizenship in 1896. From this time his children's patronymic was listed not as Frantsovichi, but as Viktorovichi.

The obituary for the death of V. (F.) V. Marechek (may the $20^{\text {th }}, 1899$ ) was not found in the local periodicals, but in the newspaper "Southern Edge" there is a notification about the half-year from the date of his death ${ }^{21}$, thanks to which the exact date of his death becomes known.

The grateful contemporaries preserved the memory about this musician: already in 1903, four and a half years after his death, he and the orchestra he directed were mentioned in the Kharkiv press: "We still remember the times when the stringed orchestra shone under the direction of the deceased kapellmeister Marechek at the Military Assembly. It is a pity that these stringed "ballroom" orchestras have become quite rare nowadays" 22 .

In different years before the beginning of the First world war, some military bands under the direction of the foreign kapellmeisters (mainly of Czechs) performed in the city, under the direction of A. F. Glavachek (the $9^{\text {th }}$ Kiev hussar regiment with its location in Chuguev in 1866-1875), the military band of the $9^{\text {th }}$ artillery brigade under the direction of the kapellmeister I. Chernik (1884) and in the late $1900^{\mathrm{s}}$, the orchestra of the $201^{\text {st }}$ Lebedinsky battalion, which was stationed in Kharkiv at that time. This group was headed by the Czech kapellmeister F. Kropa, the probable author of one of the most popular Russian military marches "Homesickness", which was published by N. V. Marechek during the Russian-Japanese war in 1904. A detailed research is devoted to the peculiarities of the creation and search for the real author of this march, carried out by the Russian researcher V. Antonov ${ }^{23}$, who relied on the materials from the bio-bibliographic dictionary "Czech musicians in Ukraine"24 and on the T. Solyanik's testimony.

21 South edge (1899). November 20 - the semi-annual day of the death of Viktor Vyacheslavovich Marechek. 19 November.

${ }^{22}$ Kharkov provincial statements (1903). Theater and music. Winter Fun at the Military Assembly. December 22.

${ }^{23}$ Antonov V. (2011). "Homesickness". Black cat in a dark room. Sunny wind. History and art magazine (electronic journal), vol.1-3. Retrieved from: https://www.vilavi.ru/pes/ toska/heimweh1.shtml; https://www.vilavi.ru/pes/toska/heimweh2.shtml; https://www.vilavi.ru/ pes/toska/heimweh3.shtml. (accessed 30 January 2020).

${ }^{24}$ Shchepakin V. M. (ed.) (2005). Czech musicians in Ukraine: Bibliographic Dictionary. Ministry of Culture and Tourism of Ukraine, Kharkiv State Academy of Culture. Kharkiv: KhDAC. 


\section{The publishing house and the music store of Nadezhda Merechek}

The mention of the N. Marechek's publishing house leads to the presentation of the second founder of the family - Nadiya Viktorivna Marechek (before getting married Chenska), who came from a Russian merchant family from Stary Oskol (now this city is administratively part of the Belgorod region of the Russian Federation).

Most likely, Franchishek and Nadiya met during the stay of the $121^{\text {st }}$ Penza infantry regiment in this city, i.e. in 1872 or 1873.

The N. Marechek's inherited from her parents talent for commercial activity (and perhaps in addition a certain amount of money) and her supposed general musical awareness, multiplied by the high professionalism of F. Marechek, made it possible for this family to start their own music publishing house and music store in Kharkiv, which was located on Moskovska Street (now Moskovsky Prospekt) in the house number 18. The family itself lived almost nearby: on Moskovskaya Street, 21. Taking into account the F. Marechek's need to devote considerable time and energy to the work as a kapellmeister with the military orchestra, one can make a logical assumption that during his lifetime, the leading role in the organization and the further prosperity of the family music-publishing and music-trading business belonged to N. Marechek.

Due to the lack of any published researches about the Marechek family, or the limited access to them in the reference ${ }^{25}$ and the scientific ${ }^{26,27}$ publications, Nadiya Marechek mistakenly represented herself as a man, since before the V. Marechek's death the store had the name of the head of the family: "Marechek's Music store", later, until 1910 - "N. Marecek's Music store".

The list of the musical works, published by F. and N. Marechek is very wide and diverse: only the funds of the Kharkiv Korolenko State Scientific Library keeps about 70 titles of the musical works by Ukrainian, Russian and Western European composers, published by N. Marechek or her successor (after 1910).

However, it is clear that there were much more musical works actually published by F. and N. Marechek's publishing house.

${ }^{25}$ Sozonova V. M., Lubenska N. V. (ed.) (2012). Ukrainian music editions in the fund of Kharkiv Korolenko State Scientific Library. (1864-1923): a catalog. Kharkiv: State Institution "Kharkiv Korolenko State Scientific Library".

${ }^{26}$ Yuferova Z. (1967). From the history of Slavic music relations. Suite "Rise of the Slavic Falcons" by V. I. Sokalsky. Ukrainian Musicology, vol. 2. Pp. 103-118.

${ }^{27}$ Yuferova Z. B. (2014). Don Sharp of the "Southern Region": gold placers of Vladimir Sokalsky's composer and musical critical heritage: a monograph. Scientific edition by E. G. Roshchenko (Averyanova). Kharkov : S.A.M. 
Among the music scores of the Kharkiv artists, that were published by the firm of N. Marechek, in addition to the above-mentioned "Homesickness", we will mention the Opinion-mazurka for piano "Poviy vitre na Vkrainu" by S. P. Drymtsov (alias Drymchenko), the Waltz for piano "My dreams" by V. Y. Katanskiy, V. I. Sokalsky's symphonic work "Gathering of Slavic falcons", the same author's song on the words of T. G. Shevchenko "Oh I have, I have" for voice and piano, a small concert fantasy for piano on two little Russian folk songs: "Oh! Am I unhappy that I need to act?" and "Oh! My mother sent me to reap the green rye" by O. V. Schulz-Evler and the same author's play for piano "Near the native home".

In the funds of the public museum "Amulets of the musical Kharkiv region", collected by Y. L. Shcherbinin, there is a number of large posters of the Kharkiv musicians and guest performers concerts, printed by $\mathrm{N}$. Marechek, therefore in addition to the popularizing the musical works of composers from different countries, the Marecheks publishing house also promoted the concerts in Moscow. In the annual reports of the Kharkiv branch of the Imperial Russian musical society of the early $1900^{\mathrm{s}}$, N. Marechek was listed among its visiting members. According to the same sources, in different years she presented the music school a portrait of M. I. Glinka and the notes ${ }^{28}$.

In addition to distributing notes and music-theoretical literature, the store of F. Marechek and later of N. Marechek also sold a wide variety of musical instruments. The T. Solyanik's archive preserved some of the N. Marecek's letters on the letterheads of the store, particularly from 1905, which show that for Kharkiv this store is the only representative of grand pianos and pianos of the Courtly factory of K. M. Schroeder in St. Petersburg, the factory of A. Grand in Berlin, the factory of T. Steinweg in Braunschweig, etc. This form also indicates that N. Marechek's store sells notes, grand pianos, pianos, violins, guitars, wind instruments and various musical accessories, as well as provides rental of grand pianos and pianos. From the numerous advertising publications of this store on the pages of the Kharkiv periodicals, the ad that was contained in the newspaper "South edge" during November-December 1903 is very indicative: "The music store of N. Marechek in Kharkiv, Moscovska Street, 18, for the upcoming holidays offers a huge selection of a wide variety of instruments, such as: Diana, Iris, Organ Iptona, Pianomelodico, Concertos folk, Zithers, Polyphonies that play themselves, Symphonion Sitella, as well as Viennese harmony, balalaikas, etc."29. Many

${ }^{28}$ Edition of the Kharkov Provincial Government (1900-1909). Reports of the Kharkov branch of the Imperial Russian Musical Society for 1901-1909. [Annual Edition]. Kharkov: Edition of the Kharkov Provincial Government.

${ }^{29}$ South edge (1903). The ads. 18 December. 
of the names used in this advertising, now unknown to the vast majority of the modern musical products consumers, were almost constantly heard centuries ago, because most of them meant varieties of mechanical musical instruments, known in Europe since the XVI century, the mass distribution of which in the Russian Empire continued in the late XIX - early XX century. These tools were used for the decoration of various public places, as well as for practical use - musical entertainment - in taverns, restaurants, barns, hotels and other places (they were activated by turning a special handle or throwing coins into a special hole).

Since the end of the XVIII century the mechanisms that played music with a software is for computers, consisting of a roller with pins (needles) and a sound comb, have become widespread. In the 80-ies of the XIX century the German engineer Paul Lohman from Leipzig proposed a new soundbox - a metal disk with teeth. Leipzig at that time was one of the centers of the musical instrumental skills. Namely in this city some new companies for the production of disk machines appeared. The largest of them were "Polyphony" and "Symphony". A large selection of such devices was offered by the Zimmerman Trading House in Leipzig ("Julius Heinrich Zimmerman"): "Stella", "Pianelli", "Symphonion", "Polyphony", "Phoenix-Inton", "Phoenix Orchestra", "Phoenix-Organ", "Herion", "Orchestra-manafon", "Piano-melodico", "Concerto-orchestrion", "Eolian-organ". As you can see, a huge variety of musical devices from this list were presented in the music store of N. Marechek.

If we add to this the fact the thing that the Zimmerman music factory in St. Petersburg produced violins, mandolins, zithers, flutes, cornets, clarinets (the list that largely coincides with the list of instruments, that were sold in the music store of N. Marechek), it becomes obvious that N. Marechek had some close trade contacts with this well-known company throughout Europe.

Since 1910 the property of the store and the music publishing house passed to E. V. Gorbunov and from that time the company was named "Trading house of E. V. Gorbunov and Co, the former N. Marechek music store". Presumably, this change of the ownership was associated with N. Marechek leaving the business: her illness or death. At least after 1910 the name of $\mathrm{N}$. Marechek appears in none of the documentary evidence we found. A confirmation of N. Marechek's death between 1910 and 1914 is also the notices about the death of Vladimir Marechek, one of the F. (V.) and N. Marecek sons, in January 1914 (he will be discussed below), which among other things, includes the following lines: "The wife, children, brothers and sisters notify the relatives and friends of the Volodymir Viktorovich Marechek's death, which happened on January the $29 \mathrm{th}^{30}$. If at that time

\footnotetext{
${ }^{30}$ South edge. (1914). The ads. 30 January.
} 
Nadiya Marechek was still alive, then of course, the list of those who announced the Volodymir's death, would begin with her - with his mother.

\section{The second generation of the Marechek musical family}

The eldest of six children (three sons and three daughters) of F. (V.) and N. Marechek, Volodymir Viktorovich (07.07.1876-29.01.1914) was an educatee of the $1^{\text {st }}$ men's gymnasium, the full course of which was completed by him in 1896, and of the law faculty of the Kharkiv Imperial University ${ }^{31}$. In the second half of the 1901/02 academic year, he studied in the music theory class, according to the report of the Kharkiv branch of the Imperial Russian musical society. According to the home archive of T. Solyanik, Volodymir Marechek had an Austrian citizenship, was Orthodox and married Evgenia Mikhailivna von Sizing, who also had a talent for music (she studied singing at the music school of the Kharkiv branch of the Imperial Russian music school in the 1899/1900 academic year). The son Eugene and the daughter Galina, who later became musicians-pianists, were born from this marriage. According to T. Solyanik, Vladimir got the Russian citizenship only after graduating from the University. As it is known from the obituaries on the death of Vladimir Viktorovich Marechek, placed in the Newspapers "Southern edge",3233, and " Kharkiv statements"34, after studying at the University, he worked in one of the local banks and later got to the position of a senior accountant of the traction service of the Southern railway. Of particular importance is the last sentence in the obituary in "Kharkiv News": "In Kharkiv, V. V. Marechek is also known as an experienced music teacher" ${ }^{35}$. Thus, the paternal genes were undoubtedly passed on to the eldest son, for whom his passion for music was of great importance in addition to his official work: apparently Vladimir had a private music teaching practice and was in demand in this field as well.

One of the daughters (probably the middle one) of Victor and Nadia Marechek - Vira (188?-1951) was a famous Kharkiv musician, as well a pianist and teacher. Her husband was a well-known cellist in the city - a concert performer, conductor and teacher - Professor Yakov Abramovich Rosenstein, who worked as the Dean of the instrumental faculty of the Kharkiv state higher music and drama courses, which were located on Pushkinskaya Street, 66 (1925), as the manager of the same courses

${ }^{31}$ Chekanov N. A. (ed). (1905). Biographical dictionary of former pets of the First Kharkov gymnasium over the past century. 1805-1905. Kharkov: "Russian Tipo-Lithography".

${ }^{32}$ South edge (1914). The ads. 30 January.

${ }^{33}$ South edge (1914). Local Chronicle. V. V. Marechek. [Obituary]. 30 January.

${ }^{34}$ Kharkov statements (1914). V. V. Marechek. [Obituary]. 30 January.

${ }^{35}$ Ibid. 
(since 1926), at the same time leading a class of cello and chamber ensemble, in 1929 he held the position of the vice-rector for the academic part of the Kharkiv music and drama Institute, which at that time was located in the building of the former music school on Sverdlova Street, 30 (formerly Ekaterinoslavskaya, now Poltavskiy Shlyakh) and led some classes for cello, chamber ensemble, conducting techniques and orchestra in this institution, and in 1930 he became the rector of the institution. In the $1920^{\mathrm{s}}$ and $1930^{\mathrm{s}}$, Vira Viktorovna Marechek-Rosenstein taught piano at the Kharkiv state higher music and drama courses (from the mid 1925 ), and at the Kharkiv music and drama Institute (since 1929) ${ }^{36}$. Probably it was Vira Marechek who was mentioned in the correspondence of the newspaper "Southern edge" (1904) about the examinations results of the piano courses students of L. G. Karpova, located on the Kontorskaya Street, 76: "The students KomenVarvatsi and Marechek already conduct the classes themselves" ${ }^{\text {"37. }}$.

The life of the middle son of F. and N. Marechek, Peter, was also connected with music. According to T. Solyanik, he was a master working with red wood, a wood carver and at the same time, probably having an perfect pitch, in $1920^{\mathrm{s}}-1930^{\mathrm{s}}$ he worked as a city authoritative master of piano repair and tuning, who had his own furniture and repair shop. In the $1920^{\mathrm{s}}$ Peter Marechek worked in the music and industry department of the $2^{\text {nd }}$ Music and professional school, and since 1930, with the organization of the technical school of music industry, the entire staff of masters of this reorganized school passed to him. P. Marechek was appointed as the head the Commission of keyboard instruments of the research laboratory at the newly created technical school. In total at the beginning of 1931 there were 8 piano masters in this Commission, but P. Marechek was probably considered the most experienced among them. This technical school existed in Kharkiv till 1933, after which it was transferred to Kiev and subsequently ceased its existence. However, during three years of operation in the city, this institution has managed to provide education for a group of technicians-designers and technicianstechnologists for the production of musical instruments ${ }^{38}$. The further fate of Peter Marechek has not yet been clarified. Interesting and not clarified in the

\footnotetext{
${ }^{36}$ Moskovkin V. (2016). On the history of Kharkov music and drama education. Experience of systematic research (1910-1940). LAP LAMBERT Academic Publishing RU. Retrieved from: http://dspace.bsu.edu.ru/bitstream/123456789/18246/1/Moskovkin_K_istorii.pdf (accessed 6 February 2020).

${ }^{37}$ South edge (1904). Public exams in music courses by L. G. Karpova. 17 May.

${ }^{38}$ Loshkov Yu. (2000). Creativity of V. A. Komarenko and folk-instrumental performance in Slobid Ukraine (First half of the twentieth century) : Dissertation ... of the candidate of the Mystic Exercise: 17.00.01 - theory and history of culture (unpublished). Kharkiv: Kharkiv State Academy of Culture. Pp. 109-111.
} 
P. Marechek's biography are the facts of his residence in the early $1900^{\mathrm{s}}$ in St. Petersburg (possibly due to the work of the music store of his mother?), evidenced by a letter from N. Marechek in 1903 from St. Petersburg, when she was visiting her son, preserved in the family archive of T. Solyanik, as well as her unexpected identification of Peter as a peasant in the late $1910^{\mathrm{s}}$ early $1920^{\mathrm{s}}$. The site of the famous Kharkiv researcher of the Slobojanshchina history A. Paramonov "Where one comes from" provides such information: "Marechek Peter Viktorovich was a peasant of the Rogan township of Kharkiv district. His wife was Efrosinia Ivanovna. The son Vyacheslav (born on 24.06.1919), was baptized on July the $22^{\mathrm{d}}$ at the Holy spirit Church in Kharkov" "39. The reasons that forced P. Marechek and his wife to move from Kharkiv to the Rogan township for some time could be the events of the civil war and the national liberation competitions in Ukraine, when the power and the political and social system in Kharkiv repeatedly changed and there was a real danger to the lives of its inhabitants.

Three more children of Franciszek and Nadiya Marechek - the eldest daughter Tatiana, the youngest one Anastasia (born in 1883, T. Solyanik's great-grandmother) and the youngest son Protas (born in 1885, chemical engineer) has chosen the musical path.

\section{The third generation of Marechek musicians}

From the number of the grandchildren of Franciszek and Nadezhda Marechek the children of their eldest son Vladimir - Evgeniy and Galina became professional musicians. Elena Nikolaevna Krasovskaya, the daughter of the youngest sister, Anastasiya Marechek, an educatee of the Kharkiv women's gymnasium of sisters Elena and Olga Pokrovski (1914-1920), who has been studying at the Kharkiv medical Institute since 1922. Despite the fact that E. Krasovskaya did not become a professional musician, her piano level was too high as for an ordinary amateur: she played perfectly and was able to sight read very complex pieces. This is indirectly evidenced by the huge music library that she collected, which is now stored in Odessa in the family archive of her daughter, Irina Antonovna Surkova (before marriage Sokolova), the mother of T. Solyanik, and the memories of these women about the capture of their mother and grandmother by piano playing, which accompanied her throughout her life (1904-08.03.1975). It is also known that the husband of A. M. Krasovskaya, the grandfather of T. Solyanik, Anton Vasilyevich Sokolov, also studied music in Kharkiv: in the family archive there is a certificate of the beginning of the $1920^{\mathrm{s}}$, issued to Anton Sokolov,

\footnotetext{
39 Paramonov A. (2010). Kharkov province. Encyclopedia of names. Where are you from. Retrieved: http://www.otkudarodom.ua/ru/node/25/\%D0\%BC (accessed 19 February 2020).
} 
which indicates that he was a student of the "Music school of the 1st group of Teachers". According to Y. L. Shcherbinin, this educational institution preceded the foundation of the $1^{\text {st }}$ State music school (now children's music school № 1 named after L. Beethoven), which was located on K. Libknecht Street (now Sumskaya), 34, initiated by the future Director of this school, an experienced pianist and teacher Mykola Oleksijovyh Khlebnikov ${ }^{40}$.

A similar characteristic of the high piano level of her mother, by a friend of A. Krasovskaya from her studies at the Pokrovski sisters girls' gymnasium, was provided in oral memories by a Professor of the Kharkiv National Kotlyarevsky University of Arts, the famous cellist E. M. Shchelkanovtseva. Obviously, in the private school of the Pokrovski sisters, as in fact in most Kharkiv women's high schools, the teaching of music and playing musical instruments, in particular the piano, was organized at a high professional level. Unfortunately, there is no documentary evidence of this fact discovered, in contrast to the presence in the local periodicals of some information about the teaching of music in some other Kharkiv women's high schools of the second half of the XIX - early XX century. (of D. D. Obolenskaya, K. L. Phillips, K. M. Drashkovskaya, etc.).

According to the assumption of T. Solyanik, A. Krasovskaya simultaneously with the medical education could have acquired music education in Kharkiv, but the conservatory archives lost during the World War II leave this thesis only as a hypothesis.

In contrast to the uncertainty about the existence of any special musical education of O. Krasovskaya, the archives of Galina Marechek's granddaughter, Olga, who now lives in South Korea, preserved the graduation diploma of Galina Marechek-Petrova, born on February the $24^{\text {th }}, 1903$, of the Kharkiv music and theater Institute in June 1930. She studied in this educational institution from October 1928, completed the practical training as a piano teacher in the children's music Studio at the Institute, played a "Concert piano program with the score of "Very good" and was qualified as a "Piano Teacher"“. As evidenced by the diploma, at the time of her graduation G. Marechek was already married to Vladimir Dmitrievich Petrov, a well known pianist and teacher in Kharkiv in the $1920^{\mathrm{s}}-1930^{\mathrm{s}}$, an educatee of the founder of the Soviet Kharkiv piano school P. K. Lutsenko, who in turn was a representative of the school of one of the best Kharkiv pianists-teachers of the late XIX - the early XX centuries, a bright concert performer and composer

\footnotetext{
${ }^{40}$ Moskovkin V. (2016). On the history of Kharkov music and drama education. Experience of systematic research (1910-1940). LAP LAMBERT Academic Publishing RU. Retrieved from: http://dspace.bsu.edu.ru/bitstream/123456789/18246/1/Moskovkin_K_istorii.pdf (accessed 6 February 2020).
} 
A. V. Shultz-Euler. No evidence of any pedagogical or performing activity of G. Marechek after her graduation from the Music and drama Institute was revealed: apparently the young woman was engaged in raising her son. However, there is some evidence of her husband's pedagogical activity: in 1925-26 V. D. Petrov taught piano at the Kharkiv state higher music and drama courses, and in 1929 he was already a member of the staff of the Kharkiv music and drama Institute, teaching first the mandatory and then the special piano ${ }^{41}$.

The Museum "Amulets of musical Kharkiv region" contains a rare photo of the late $1920^{\mathrm{s}}$, which shows the famous musicologist, teacher and composer, future Professor and rector (in May-October 1941) of the Kharkiv Conservatory and at that time Professor and head of the Department of theory and composition of the Kharkiv music and drama Institute S. S. Bogatyrev with the students of his class: O. Adlivankina, M. Polevsiy, V. Arkina, G. Marechek, A. Lavrova (after marriage Shcherbinina) - the mother of L. Y. Shcherbinin, a close friend of G. Marechek, and M. Itigina. The same photo is contained in the Ukrainian Wikipedia in the article about S. S. Bogatyrev. It is important to note that according to Y. L. Shcherbinin, the piano teacher of A. Lavrova-Shcherbinina was V. D. Petrov - the husband of her friend G. Marechek. Unfortunately, the talented pianist G. V. Marechek died suddenly in 1938 at the age of 35 from a heart attack.

According to the results of some persistent searches by T. Solyanik, it was found that Galina's older brother, Evgeny Vladimirovich Marechek (20.10.1898 - 22.05.1979), studied piano privately in Kharkiv with a prominent Kharkiv pianist and composer of Polish origin, a graduate of the Leipzig Conservatory in the class of a student of F. Liszt, A. Reisenauer, a former teacher of the Klinworth-Sharvenka Conservatory in Berlin (1904-1914), Sergei Eduardovich Bortkevich before his emigration in 1920.

According to the Internet correspondence of T. Solyanik with one of the students of E. Marechek at the Prague Conservatory, the contemporary wellknown Czech organist Jan Gore, as well as the answers from the Prague Conservatory on her requests to the archives of this institution, succeeded in the approximate reconstruction of the Czech period of life and teaching of this former Kharkiv citizen.

Thus, according to the answers from the Czech Republic, E. Marechek studied in the Kharkiv gymnasium (college -? - V. Shchepakin),

${ }^{41}$ Moskovkin V. (2016). On the history of Kharkov music and drama education. Experience of systematic research (1910-1940). LAP LAMBERT Academic Publishing RU. Retrieved from: http://dspace.bsu.edu.ru/bitstream/123456789/18246/1/Moskovkin_K_istorii.pdf (accessed 6 February 2020). 
in 1920-24 - at the Kharkov Music Institute. In 1925 the 27-year-old Evgeny Marechek managed to leave the Soviet Union for the Czech Republic (probably with the permission of A. V. Lunacharsky for Soviet students of foreign origin to study abroad), where in 1925-27 and 1928-29 he continued his musical education at the Prague Conservatory with the outstanding Czech piano teacher and methodologist, professor William Kurz, who during his 21 - year (1898-1919) resultful work in Lviv, and then many years of work at the Prague Conservatory, became a teacher of a number of famous Galician musicians-pianists and composers: M. Kolessa, G. Savitsky, V. Barvinsky, D. Zador, T. Shukhevich, N. Nizhankivsky and others.

In 1929-33 E. Marechek studied at the School of Excellence of the Prague Conservatory in the class of the famous pianist, the founder of the "Czech Trio", the author of many works on the theory and history of music, the music writer, Professor Karel Hoffmeister, having received a master's degree on 28.06.1933. In 1933-39 the pianist was engaged in private teaching and concert activities and on 23.10.1939 he began teaching as a tutor at the Prague Conservatory. Since 01.03.1944 E. Marechek was transferred to the position of a teacher (under contract) and after the separation in 1945 of The Academy of performing arts as a higher educational institution from The Prague Conservatory, which since that time has been training specialists with secondary special education, E. Marechek was a Professor at the Conservatory from 01.01.1948, in 1946-48 he directed the piano performing practice. Marechek worked until his retirement in July 1961, but in 1966-69 he returned to work at the Conservatory as a consultant.

It is known from some Czech sources that in 1945-49 E. Marechek along with other leading professors of The Prague Conservatory - V. Kurtz, V. Kapral, L. Kundera, L. Mikelka, V. Polevka and others - participated in the editing and publishing of 31 notebooks of instrumental music (instructional sketches, plays by R. Schuman, P. Tchaikovsky, works by J. S. Bach, V. A. Mozart, L. Beethoven, F. Chopin and others) ${ }^{42}$.

Among his students (graduates) there were some Czech musicians: the chorus master, concert pianist and harpsichordist Vladiviy Yankovsky (1922-2007), the conductor Bogumil Berka (1921-2004), the chorus master, conductor, teacher and composer Jan Kasal (1923), the conductor and composer Peter Dubravsky (1925-2004), Dagmar Shkodova, the abovementioned Jan Gore (1936), and others. Thus, judging by the further spheres of music activity of E. Marechek's students, we can conclude that he

\footnotetext{
${ }^{42}$ Pašek M (2019). Edice pražské konservatoře. Ceský hudebni slovnik osob a institucí. Retrieved from: http://www.ceskyhudebnislovnik.cz/slovnik/index.php?option=com mdictionary\&task=record.record_print\&tmpl=component\&id=3798 (accessed 06 February 2020).
} 
conducted a class of the most common piano for students who did not have this instrument as the main. Despite this, Jan Gore lists the name of the piano teacher E. Marechek in the list of his best conservatory teachers: along with the organist Jan Bedrich Krays and the theorist and composer Zdenek Hula ${ }^{43}$.

According to the same J. Gora, only in 1958 at the age of 60 E. Marechek married his longtime Czech acquaintance, a primary school teacher Maria Mateykova, born in 1922. His wife predeceased him. There were no children in this marriage. So, as we can see, more than half a century after Franciszek Marechek's departure from the Czech Republic, one of his grandchildren returned to his historical homeland, where he continued his grandfather's business - bringing up many well-known Czech musicians of the second half of XX - early XXI centuries.

Now the descendants of Franciszek and Nadezhda Marechek live in Kharkov (the village Naukove), Odessa, Moscow, South Korea, Finland. Perhaps some of them will continue the musical work of their ancestors over time.

\section{CONCLUSIONS}

The attempt to reconstruct the biography fragments and to highlight the diverse musical activities of three generations of the Kharkiv Czech-Russian Marechek family confirms the weight of the contribution of many of its representatives to the development of the musical life of one of the largest Ukrainian cultural centers, which became their homeland, the family continuity in choosing the profession, peculiar to many musical families of different nationalities, the sincere and dedicated serving the development of various fields of musical activity (military orchestral performance, trade and publishing spheres, music pedagogy, piano performance, organization of pianos repair and manufacture, etc.).

E. V. Marechek's position as a Professor at one of the oldest European conservatories in Prague, as well as the presence of a number of mysterious and yet unexplained facts from the biographies of this family members, provides the prospect of further scientific research in this direction.

\section{SUMMARY}

The subject of the research is the versatile musical activity in Kharkiv of three generations of the Marechek family. The analysis and the understanding of the accomplished search for some scattered evidence and facts, related to

\footnotetext{
${ }^{43}$ Kulijevyčová M. (2008). Ve světě kláves, pedálů, píštal a rejstř́iků - profil varhaníka Jana Hory. Harmonie: klasická hudba, jazz a world music. 5. únor. Retrieved from: https://www.casopisharmonie.cz/rozhovory/ve-svete-klaves-pedalu-pistal-a-rejstriku-profilvarhanika-jana-hory.html?fbclid=IwAR1bWz1LdDFSq1M2i-JysHu9OpqqjoBN98hyXz75MI0 uKWi90ifZ6lm-PwQ (accessed 07 February 2020).
} 
the life and work in the city of the Marechek family representatives, required the use of a historical approach, the method of biographical reconstruction and the musical-local lore history method.

The results of this work made it possible for the first time in the Ukrainian musicology to present a number of bright personalities - representatives of three generations of musicians of this family, whose activities cover almost a century, and partially reconstruct their life and creative paths against the background of the historical and political events that took place in the Russian Empire - the Soviet Union.

The contribution of the Marechek family representatives to the development of many components of Kharkiv's musical culture has been proven: the military orchestral performance, music publishing, music trade, music production, music and pedagogical spheres.

Emphasized on the great musical and educational importance of the work of F. V. Marechek in the position of kapellmeister of the $121^{\text {st }}$ Penza infantry regiment.

The personality of E. V. Marechek and the lighting of his work as a Professor of the piano playing class at The Prague Conservatory is presented for the first time. The list of names of a number of famous Czech musicians students of the piano class of E. V. Marechek at the Prague Conservatory is given.

\section{REFERENCES}

1. Antonov V. (2011). “Toska po Rodine”. Chyornaya koshka v tyomnoj komnate. ["Homesickness". Black cat in a dark room]. Solnechnyy veter. Istoriko-khudozhestvennyy zhurnal. [Sunny wind. History and art magazine] (electronic journal), vol. 1-3. Retrieved from: https://www.vilavi.ru/ pes/toska/heimweh1.shtml; https://www.vilavi.ru/pes/toska/heimweh2.shtml; https://www.vilavi.ru/pes/toska/heimweh3.shtml (accessed 30 January 2020). (in Russian).

2. Balyazin V. N. (2007) Neofitsial'naya istoriya Rossii. [Unofficial History of Russia]. Moscow: OLMA Media Group, 2007. (in Russian).

3. Chekanov N. A. (ed). (1905). Biograficheskij slovar byvshih pitomcev Pervoj Harkovskoj gimnazii za istekshee stoletie. 1805-1905. [Biographical dictionary of former pets of the First Kharkov gymnasium over the past century. 1805-1905]. Kharkov: "Russian Tipo-Lithography". (in Russian).

4. Edition of the Kharkov Provincial Government (1900-1909). Otchety KHar'kovskogo otdeleniya Imperatorskogo Russkogo muzykalnogo obshestva za 1901-1909 gody. [Ezhegodnoe izdanie]. (1902-1910). [Reports of the Kharkov branch of the Imperial Russian Musical Society for 1901-1909. [Annual Edition]]. Kharkov: Edition of the Kharkov Provincial Government. (in Russian). 
5. Kharkov provincial statements (1889). Hronika. [The Chronicle]. 28 April. (in Russian).

6. Kharkov provincial statements (1899). Chastnye obyavleniya. [Private Ads.] 25 February. (in Russian).

7. Kharkov provincial statements (1903). Teatr i muzyka. [Zimnie uveseleniya $v$ Voennom sobranii]. [Theater and music. [Winter Fun at the Military Assembly]]. 22 December. (in Russian).

8. Kharkov provincial statements. (1876). CHast' neofitsial'naya. [O vystuplenii orkestra 121 pehotnogo Penzenskogo polka pod rukovodstvom F. Marecheka]. [The part is unofficial. [On the performance of the $121^{\text {th }}$ Penza Infantry Regiment's Orchestra led by F. Marechek]]. 5 September. (in Russian).

9. Kharkov statements (1914). V. V. Marechek [Nekrolog]. [V. V. Marechek. [Obituary]]. 30 January. (in Russian).

10. Kulijevyčová M. (2008). Ve světě kláves, pedálů, píšt’al a rejstř́ků profil varhaníka Jana Hory. Harmonie : klasická hudba, jazz a world music. 5. únor. Retrieved from: https://www.casopisharmonie.cz/rozhovory/ve-sveteklaves-pedalu-pistal-a-rejstriku-profil-varhanika-janahory.html?fbclid=IwAR1bWz1LdDFSqlM2i-

JysHu9OpqqjoBN98hyXz75MI0uKWi90ifZ6lm-PwQ (accessed 7 February 2020). (in Czech).

11. Levchenko A. (2007). Kak harkovchane s turkami srazhalis. [How Kharkiv citizens fought with the Turks]. Evening Kharkov. 12 March. (in Russian).

12. Loshkov Yu. (2000). Tvorchist' $V$. A. Komarenka $i$ narodnoinstrumentalne vykonavstvo $v$ Slobids'kij Ukrayini (Persha polovina 20 stolittya) [Creativity of V. A. Komarenko and folk-instrumental performance in Slobid Ukraine (First half of the twentieth century)]: Dissertation... of the candidate of the Mystic Exercise: 17.00.01 - theory and history of culture (unpublished). Kharkiv: Kharkiv State Academy of Culture. (in Ukraine).

13. Moskovkin V. (2016). $\mathrm{K}$ istorii harkovskogo muzykalnogo i dramaticheskogo obrazovaniya. Opyt sistematicheskogo issledovaniya (1910-1940 gg.). [On the history of Kharkov music and drama education. Experience of systematic research (1910-1940)]. LAP LAMBERT Academic Publishing RU. Retrieved from: http://dspace.bsu.edu.ru/bitstream/123456789/ 18246/1/Moskovkin_K_istorii.pdf. (accessed 6 February 2020). (in Russian).

14. Paramonov A. (2010). KHar'kovskaya guberniya. Enciklopediya familij. [Kharkov province. Encyclopedia of names]. Otkuda rodom. [Where are you from]. Retrieved: http://www.otkudarodom.ua/ru/node/25/\%D0\%BC (accessed 19 February 2020). (in Russian). 
15. Pašek M (2019). Edice pražské konservatoře. Ceský hudební slovník osob a instituci. Retrieved from: http://www.ceskyhudebnislovnik.cz/ slovnik/index.php?option=com_mdictionary\&task=record.record_print\&tmpl $=$ component $\& i d=3798$ (accessed 6 February 2020). (in Czech).

16. Rudenko V. I. (1984). Vyacheslav Ivanovich Souk: Popular monograph. [Vyacheslav Ivanovich Suk : Popul. monogr]. Moscow: Music. (in Russian).

17. Schenk V. K. (1909). Grenaderskiye i pekhotnyye polki. 121-y Pekhotnyy Penzenskiy General-Fel'dmarshala Grafa Milyutina polk. [Grenadier and Infantry regiments. $121^{\text {st }}$ Infantry Penza General Field Marshal Count Milyutin Regiment]. Reference book of the Imperial Headquarters. Voyennaya entsiklopediya Sytina, t. 18. [Military encyclopedia of Sytin, vol. 18]. Retrieved from: http://www.imha.ru/1144528148pexotnyj-121-go-penzenskij-general-feldmarshala.html\#.XjsVLDIzbbh (accessed 29 January 2020). (in Russian).

18. Shchepakin V. M. (2001). Diyal'nist' ches'kykh viys'kovykh kapel'meysteriv $\mathrm{v}$ Ukrayini $\mathrm{v}$ druhiy polovyni XIX - na pochatku XX st. [Activity of Czech military capmillers in Ukraine in the second half of XIX early XX centuries.] Culture of Ukraine. Art Studies, vol. 8. pp. 198-205. (in Ukrainian).

19. Shchepakin V. M. (2017). Muzychna kul'tura Skhodu i Pivdnya Ukrayiny druhoyi polovyny XIX pochatku XX stolit': yevropeys'ki vymiry : monohrafiya [Musical culture of the East and South of Ukraine in the second half of the $19^{\text {th }}$ - beginning of the $20^{\text {th }}$ centuries : European dimensions : monograph]. Kharkiv : FOP Panov A.M. (in Ukrainian).

20. Shchepakin V. M. (ed.) (2005). Ches'ki muzykanty v Ukrayini : Biobibliohrafichnyy slovnyk [Czech musicians in Ukraine: Bibliographic Dictionary]. Ministry of Culture and Tourism of Ukraine, Kharkiv State Academy of Culture. Kharkiv: KhDAC. (in Ukrainian).

21. Solyanik T. E. (2015). Frantishek Vojcehovich Marechek. [Frantisek Wojciechowicz Marecek]. (unpublished). (in Russian).

22. South edge (1896). Obyavleniya. [The ads]. 1 February. (in Russian).

23. South edge (1897). Abissinskaya vystavka. [Abyssinian exhibition]. December 1. (in Russian).

24. South edge (1897). Abissinskij voennyj marsh. [Abyssinian Military March]. December 8. (in Russian).

25. South edge (1899). 20 noyabrya - polugodovoj den konchiny Viktora Vyacheslavovicha Marechek. [November 20 - the semi-annual day of the death of Viktor Vyacheslavovich Marechek]. 19 November. (in Russian).

26. South edge (1903). Obyavleniya. [The ads]. 18 December. (in Russian). 
27. South edge (1904). Publichnyye ekzameny na muzykal'nykh kursakh L. G. Karpovoy. [Public exams in music courses by L. G. Karpova]. 17 May. (in Russian).

28. South edge (1914). Mestnaya hronika. V. V. Marechek [Nekrolog]. [Local Chronicle. V. V. Marechek. [Obituary]]. 30 January. (in Russian).

29. South edge. (1897). Muzykantskie ucheniki. [Music students]. 15 February. (in Russian).

30. South edge. (1914). Obyavleniya. [The ads]. 30 January. (in Russian).

31. Sozonova V. M., Lubenska N. V. (ed.) (2012). Ukrayinski notni vidannya $u$ fondi Harkivskoyi derzhavnoyi naukovoyi biblioteki im. V. G. Korolenka (1864-1923) : katalog. [Ukrainian music editions in the fund of Kharkiv Korolenko State Scientific Library. (1864-1923) : a catalog]. Kharkiv: State Institution "Kharkiv Korolenko State Scientific Library". (in Ukrainian).

32. Tutunov V. I. (1961). 250 let voenno-orkestrovoj sluzhby v Rossii (kratkij istoricheskij ocherk). [250 years of military service in Russia (brief historical sketch)]. Trudy voyenno-dirizhërskogo fakul'teta pri MGK im. P. I. CHaykovskogo. [Proceedings of the military conducting faculty at the Moscow Tchaikovsky State Conservatory]. Moscow: Moscow Tchaikovsky State Conservatory. Vol. 5. pp. 126-140. (in Russian).

33. Vojnikov I. (2017). Istoriya na blgarskite drzhavni simvoli. [History of Bulgarian national symbols]. V. Turnovo: Abagar. P. 97. (in Bulgarian).

34. Yuferova Z. (1967). Z istoriyi slov'yans'kykh muzichnih zv'yazkiv. Syuyita "Zlit sokoliv slov'yans'kih" V. I. Sokal's'koho [From the history of Slavic music relations. Suite "Rise of the Slavic Falcons" by V. I. Sokalsky]. Ukrayins'ke muzykoznavstvo [Ukrainian Musicology], vol. 2. pp. 103-118. (in Ukrainian).

35. Yuferova Z. B. (2014). Don-Diez "Yuzhnogo kraya": zolotye rossypi kompozitorskogo i muzykalno-kriticheskogo naslediya Vladimira Sokalskogo : monohrafiya. [Don Sharp of the "Southern Region": gold placers of Vladimir Sokalsky's composer and musical critical heritage : a monograph]. Scientific edition by E. G. Roshchenko (Averyanova). Kharkov : S.A.M. (in Russian).

\section{Information about the author: Vasyl Shchepakin,}

Doctor of Art criticism (hab.dr), Docent, Associate Professor at the Department of History and Theory of Music Kharkiv State Academy of Culture, Kharkiv 4, Bursatski Uzviz, Kharkiv, 61057, Ukraine orcid.org/0000-0001-7616-9687 